\title{
Bioline International
}

\section{Insect Science and its Application}

Search all documents for

Insect Science and its Application, Vol. 21, No. 4, 2001, 403-407

Bioline code:ti01050

Price of single document: US\$13.00

\section{IMPACT OF SOLAR RADIATION, RAINFALL AND CANNIBALISM ON DISAPPEARANCE OF MAIZE STEMBORERS IN KENYA}

\section{M.J. BONHOF AND W.A. OVERHOLT}

\section{ABSTRACT}

The effect of solar radiation, rainfall and cannibalism on the disappearance of eggs and larvae of the cereal stemborer Chilo partellus $\mathrm{s}$ (Swinhoe) were studied. Disappearance and nonviability of egg batches was higher on plants exposed to solar radiation than on shaded plants. Significantly fewer small larvae were recovered from plants exposed to rainfall than from shielded plants. Cannibalism among larvae of the same size was not common except at high larval densities. Contrary to the common belief that disappearance is the result of predation, these studies show that solar radiation and rainfall might also play an important role in the disappearance of stemborer eggs and small larvae.

Keywords: solar radiation, rainfall, cannibalism, disappearance, Chilo partellus, maize

\section{RÉSUMÉ}

Les effets des radiations solaires, de la pluie et du cannibalisme sur la disparition des oeufs et des larves du foreur des tiges de céréale Chilo 
partellus (Swinhoe) ont é té étudiés. La disparition et la non-viabilité des pontes sont plus importantes sur les plantes exposées aux radiations solaires que sur celles situé es à l'ombre. Le nombre de jeunes larves retrouvées sur les plantes exposées aux pluies est significativement plus faible que sur les plantes protégées. Le cannibalisme entre les larves de même taille n'est pas commun sauf si les densités de larves sont é levées. Contrairement à ce qui est communé ment admis, à savoir que la disparition est le ré sultat de la pré dation, ces études montrent que les radiations solaires et la pluie peuvent aussi jouer un rôle important dans la disparition des oeufs et des jeunes larves de foreurs des tiges.

Mots Clés radiations solaires, pluie, cannibalisme, disparition, Chilo partellus, maï $s$

(C) Copyright 2001 - The International Centre of Insect Physiology and Ecology 